\title{
EFFECTS OF SHIFT WORK ON DIETARY HABITS AND NUTRIENTS INTAKE OF SECURITY GUARDS
}

\author{
By
}

Abdel Hamied AM ${ }^{1}$, Elhadidy SS ${ }^{1}$ and El-Sabakhawi $\mathrm{DH}^{2}$

${ }^{1}$ Department of Public Health and Community Medicine, Faculty of Medicine, Mansoura University, Mansoura, Egypt , , ${ }^{2}$ Department of Field and Research Studies, National Nutrition Institute, Cairo, Egypt

Corresponding author: Elhadidy SS: samah.elhadidy@man.edu.eg

\begin{abstract}
Introduction: Shift work means working at times out of normal daylight hours (8:00 am to 2:00 pm) or work during the weekends. Also it refers to a work schedule that involves irregular or unusual hours, such as night work and rotating shift work, in contrast to normal daytime work. Shift workers prefer to eat fast foods and tend to have fewer meals over 24 hours. Security guards experience shifts that negatively affect their dietary behavior and nutritional status. Aim of work: To assess the effect of shift work on dietary habits and nutrients intake among the security guards at Mansoura University. Materials and methods: A cross sectional study of all (166) security guards at Mansoura University who were exposed to an interviewer-administrated questionnaire for socio-demographic data and occupational history, anthropometric measurement, evaluation of dietary habits and dietary survey. Results: Mean \pm SD of Body Mass Index (BMI) (34.6 \pm 8.8 ) and waist circumference $(105.1 \pm 15.9 \mathrm{~cm})$ were statistically significantly higher among night shift guards than those with other shifts. Number of meals was statistically significantly fewer (2 meals/day) but snacks number was significantly higher (> 3 snacks/day) among night shift guards. Night shift guards had the highest daily carbohydrate and fat intake and lowest daily protein intake with a statistically significant difference with other shifts. They also had the lowest daily intake of iron, calcium and vitamin. Conclusion: Security guards with night shift experienced few meals intake with more snacks during their shift with reduced intake of protein, iron, calcium and vitamin A and with increased carbohydrate and fat intake.
\end{abstract}

Key words: Security workers, Dietary habits, Nutrients, Vitamins and Shift work. 


\section{Introduction}

Shift work is working at times out of normal daylight hours (8:00 am to 2:00 pm) or work during the weekends (Ghiasvand et al., 2006). Also it refers to a work schedule that involves irregular or unusual hours, such as night work and rotating shift work, in contrast to normal daytime work (Morshead, 2002).

Security guards are responsible for guaranteeing the security and the physical integrity of employees, workers and visitors, in public institutions, like universities and they work in shifts to be constantly alert to any circumstance that threatens the security (Godinho et al., 2016).

Morikawa et al., (2008) stated that shift workers preferred to eat fast foods and tend to have fewer meals over 24 hours. Several mechanisms explain weight gain among shift workers, such as higher calorie intake, changes in dietary habits such as eating fewer meals, more snacks and in the circadian distribution of food intake and lower physical exercise. The impact of shift work on nutrient intake differed by age and the type of shift work. Also, Waterhous et al., (2003) agreed that shift work affects the distribution of food intake and the selection of food items over 24 hour. Modifying external factors such as food and beverage intake patterns can help to reduce the destructive health effects of shift work (Berger and Hobbs, 2006).

Ohtsuka (2001) studied female workers in a computer factory in Japan and found that shift workers, particularly those with night shifts, took smaller amounts of energy, protein, fat, carbohydrate, calcium and iron than the daytime workers, implying that the former group's nutritional status has been worsened, judged from the recommended dietary allowance for Japanese. Their inadequate nutrient intake was due to lower meal frequency and poor meal quality, both of which were conditioned by shift work.

There is a dearth of knowledge about the relationship between shift work and diet in Egypt.

This study highlights how the dietary habits can be affected by shift work among the security guards working in shift.

\section{Aim of work}

To assess the effect of shift work on dietary habits and nutrients intake among the security guards at Mansoura University. 


\section{Material and methods}

Study design: It is a cross sectional study.

\section{Place and duration of the study:}

The study was conducted in Mansoura University during the period from April till October 2016.

Study sample: A convenience sample of all (166) security guards (127 males, 39 females) who are classified according the type of their work shift into:

1. Those who work in day shift (number $=63$ ), they work from 8.00 am to $3.00 \mathrm{pm}$.

2. Those who work in evening shift (number $=39$ ), they work from 3.00 pm-8.00 pm.

3. Those who work in night shift (number $=64)$, they work from 8.00 pm-8.00 am.

\section{Study methods:}

1. An interviewer-administrated semi-structured questionnaire fulfilling the requirements of the study to collect: socio-demographic data: such as age, gender, residence, marital status and educational level, occupational history: as type of shift work, working hours/day and the duration of employment.

2. Anthropometry: including:

i. Measurement of weight and height according to WHO (World health organization) standard protocol. In the present study, first, the subjects' weight was measured in terms of $\mathrm{Kg}$ using a digital balance then their heights were measured in terms of meter using a mobile stadiometer (WHO, 1995).

ii. The Body Mass Index (BMI) (defined as weight in $\mathrm{kg} /$ height in meter square) was also calculated to reflect the nutritional status of the studied group (WHO, 2006).

iii. The waist circumference was measured as the midway between the lower rib margin and the superior anterior iliac spine (WHO, 2008).

3. Evaluation of dietary and smokinghabits: each participant was asked about the number of meals taken per day, the main meal taken, the number of snacks/day and their types, the time of last meal and smoking history.

4. Dietary survey: Dietary intake was assessed by using 24-hour recall. Each participant was instructed to record the food items taken and the approximate 
quantity of each item consumed during each meal. Quantities were expressed in household measures. The inventories were checked by an experienced nutritionist, who verified the type and the quantities of the recalled foods. The daily dietary intakes of energy (carbohydrate, protein and fat), minerals ( iron, calcium, sodium, potassium and phosphorus) and vitamins (vitamin $\mathrm{A}$, vitamin $\mathrm{C}$, thiamine and riboflavin) consumed in each meal by each participant were analyzed at the National Nutrition Institute using the food composition tables for Egypt (National Nutrition Institute, 2007).

\section{Consent}

An informed verbal consent was obtained from the security guards at Mansoura University, to participate voluntarily in the study with assurance of confidentiality of data.

\section{Ethical approval}

Approval of the Institutional Review Board (IRB) of Faculty of Medicine, Mansoura University was obtained

\section{Data management}

Data were fed to the computer and statistically analyzed using the Statistical Package for Social Sciences (SPSS) version 20. Qualitative data were described using number and percent. Quantitative data were described using median (minimum and maximum) \& inter quartile range for non parametric data and mean, standard deviation for parametric data after testing normality using Kolmogrov-Smirnov test. $\mathrm{P}$ value $\leq 0.05$ (5\%) was considered to be statistically significant.

The used tests: Chi-square test: for categorical variables, to compare between different groups, One Way ANOVA: for parametric quantitative variables to compare between more than two studied groups with post hoc LSD for pairwise comparison , Kruskal Wallis test: for non parametric quantitative variables to compare between more than two studied groups and Mann Whitney test: for non parametric quantitative variables, to compare between two studied groups. 


\section{Results}

Table (1): Socio-demographic characteristics of security guards according to the type of their work shift.

\begin{tabular}{|c|c|c|c|c|c|}
\hline & $\begin{array}{l}\text { Day } \\
\text { shift } \\
(\mathrm{No}=63)\end{array}$ & $\begin{array}{c}\text { Evening } \\
\text { shift } \\
\text { (No=39) }\end{array}$ & $\begin{array}{c}\begin{array}{c}\text { Night } \\
\text { shift }\end{array} \\
\text { (No=64) }\end{array}$ & $\begin{array}{c}\text { Test of } \\
\text { significance }\end{array}$ & Total \\
\hline Age (years) & No $(\%)$ & No $(\%)$ & No $(\%)$ & & No $(\%)$ \\
\hline$\bullet \quad<30$ & $28(44.4)$ & $20(51.3)$ & $34(53.1)$ & \multirow{3}{*}{$\begin{array}{l}\chi^{2}=7.87 \\
p=0.09\end{array}$} & $82(49.4)$ \\
\hline - $30-40$ & $26(41.3)$ & $10(25.6)$ & $13(20.3)$ & & $49(29.5)$ \\
\hline - $\quad>40$ & $9(14.3)$ & $9(23.1)$ & $17(26.6)$ & & $35(21.1)$ \\
\hline \multicolumn{6}{|l|}{ Sex } \\
\hline Male & $45(71.4)$ & $32(82.1)$ & $50(78.1)$ & \multirow[t]{2}{*}{$\begin{array}{l}\chi^{2}=1.7 \\
p=0.44\end{array}$} & $\begin{array}{c}127 \\
(76.5)\end{array}$ \\
\hline Female & $18(28.6)$ & $7(17.9)$ & $14(21.9)$ & & $39(23.5)$ \\
\hline \multicolumn{6}{|l|}{ Residence } \\
\hline Rural & $49(77.8)$ & $34(87.2)$ & $50(78.1)$ & \multirow{2}{*}{$\begin{array}{l}\chi^{2}=1.6 \\
p=0.45\end{array}$} & $133(80.1)$ \\
\hline Urban & $14(22.2)$ & $5(12.8)$ & $14(21.9)$ & & $14(21.9)$ \\
\hline \multicolumn{6}{|l|}{ Marital status } \\
\hline Single & $15(23.8)$ & $5(12.8)$ & $18(28.1)$ & \multirow{2}{*}{$\begin{array}{c}\chi^{2}=3.3 \\
p=0.19\end{array}$} & $38(22.9)$ \\
\hline Married & $48(76.2)$ & $34(87.2)$ & $46(71.9)$ & & $128(77.1)$ \\
\hline \multicolumn{6}{|l|}{ Educational level } \\
\hline $\begin{array}{l}\text { Illiterate and } \\
\text { basic }\end{array}$ & $26(41.3)$ & $9(23.1)$ & $12(18.8)$ & \multirow[t]{3}{*}{$\begin{array}{l}\chi^{2}=8.9 \\
p=0.06\end{array}$} & $47(28.3)$ \\
\hline Secondary & $27(42.9)$ & $21(53.8)$ & $35(54.7)$ & & $83(50.0)$ \\
\hline University & $10(15.9)$ & $9(23.1)$ & $17(26.6)$ & & $36(21.7)$ \\
\hline \multicolumn{6}{|l|}{$\begin{array}{ll}\text { Duration } & \text { of } \\
\text { employment: } & \\
\end{array}$} \\
\hline$\cdot \quad<5$ years & $28(44.4)$ & $20(51.3)$ & $34(53.1)$ & \multirow{3}{*}{$\begin{array}{c}\chi^{2}=8.2 \\
p=0.08\end{array}$} & $82(49.4)$ \\
\hline - 5-10 years & $10(15.9)$ & $10(25.6)$ & $18(28.1)$ & & $38(22.9)$ \\
\hline - $\quad>10$ years & $25(39.7)$ & $9(23.1)$ & $12(18.8)$ & & $46(27.7)$ \\
\hline
\end{tabular}

2: chi square test 
Table (1) showed that $49.4 \%$ of the security guards at Mansoura University were below 30 years old, $76.5 \%$ were males, $80.1 \%$ were rural residents, $77.1 \%$ were married, $50.0 \%$ completed the secondary level of education and $49.4 \%$ had duration of employment less than 5 years. There were no statistically significant differences as regards the socio-demographic characteristics of the security guards according to the type of their shift work $(\mathrm{P}>0.05)$.

Table (2): Distribution of anthropometric measures of the security guards according to the type of their work shift.

\begin{tabular}{|l|c|c|c|c|c|}
\hline \multicolumn{1}{|c|}{$\begin{array}{c}\text { Anthropometric } \\
\text { measures }\end{array}$} & Day shift & Evening shift & Night shift & $\begin{array}{c}\text { Test of } \\
\text { significance }\end{array}$ & p value \\
\hline BMI: & (No=63) & (No=39) & & F $=8.8$ & $\mathbf{p}<\mathbf{0 . 0 0 1 * *}$ \\
Mean \pm SD & $28.8 \pm 4.7^{\mathrm{A}}$ & $30.39 \pm 4.7^{\mathrm{B}}$ & $34.6 \pm 8.8^{\mathrm{AB}}$ & & \\
\hline $\begin{array}{c}\text { Waist circumference: } \\
\text { Mean } \pm \mathrm{SD}\end{array}$ & $90.3 \pm 18.9^{\mathrm{A}}$ & $91.88 \pm 15.4^{\mathrm{B}}$ & $105.12 \pm 15.9^{\mathrm{AB}}$ & $\mathrm{F}=9.79$ & $\mathbf{p}<\mathbf{0 . 0 0 1} * *$ \\
\hline
\end{tabular}

F: One Way ANOVA test

BMI: Body Mass Index

A/B: Similar letters denote significant difference between groups in same row

**: Highly statistically significant

Table (2) showed that the BMI was statistically significantly higher among security guards with night shift $(34.6 \pm 8.8)$ than those with evening $(30.39 \pm 4.7)$ and day shifts $(28.8 \pm 4.7)(\mathrm{P}<0.001)$. Also, the waist circumference was statistically significantly higher among those with night shift $(105.12 \pm 15.9)$ than those with evening $(91.88 \pm 15.4)$ and day shifts $(90.3 \pm 18.9)(\mathrm{P}<0.001)$. 
Table (3): Distribution of dietary and smoking habits among the security according to the type of their work shift.

\begin{tabular}{|c|c|c|c|c|c|c|c|c|}
\hline \multirow[t]{2}{*}{$\begin{array}{c}\text { Dietary and } \\
\text { smoking habits }\end{array}$} & \multicolumn{2}{|c|}{$\begin{array}{r}\text { Day } \\
\text { shift } \\
(\mathrm{No}=63) \\
\end{array}$} & \multicolumn{2}{|c|}{\begin{tabular}{|c|} 
Evening shift \\
$(\mathrm{No}=39)$ \\
\end{tabular}} & \multicolumn{2}{|c|}{$\begin{array}{l}\text { Night shift } \\
(\text { No=64) }\end{array}$} & \multirow[t]{2}{*}{$\begin{array}{c}\text { Test of } \\
\text { significance } \\
(\chi 2)\end{array}$} & \multirow[t]{2}{*}{$p$ value } \\
\hline & No & $\%$ & No & $\%$ & No & $\%$ & & \\
\hline $\begin{array}{c}\text { No of meals/day } \\
2 \\
3 \\
>3 \\
\end{array}$ & $\begin{array}{l}15 \\
35 \\
13 \\
\end{array}$ & $\begin{array}{l}23.8 \\
55.6 \\
20.6\end{array}$ & $\begin{array}{c}15 \\
17 \\
7 \\
\end{array}$ & $\begin{array}{l}38.5 \\
43.6 \\
17.9 \\
\end{array}$ & $\begin{array}{r}44 \\
17 \\
3 \\
\end{array}$ & $\begin{array}{c}68.7 \\
26.6 \\
4.7 \\
\end{array}$ & 27.7 & $\mathrm{p}<0.001 * *$ \\
\hline $\begin{array}{c}\text { No of snacks/day: } \\
\text { NO Snacks } \\
1-3 \text { times } \\
>3 \text { times }\end{array}$ & $\begin{array}{c}9 \\
50 \\
4\end{array}$ & $\begin{array}{c}14.3 \\
79.4 \\
6.3\end{array}$ & $\begin{array}{c}2 \\
32 \\
5\end{array}$ & $\begin{array}{c}5.1 \\
82.1 \\
12.8\end{array}$ & $\begin{array}{c}2 \\
27 \\
35\end{array}$ & $\begin{array}{c}3.1 \\
42.2 \\
54.7\end{array}$ & 45.9 & $\mathrm{p}<0.001 * *$ \\
\hline $\begin{array}{l}\text { Time of last meal: } \\
\text { Before 9pm } \\
9 \mathrm{pm}-12 \mathrm{am} \\
\text { After } 12 \mathrm{am}\end{array}$ & $\begin{array}{c}18 \\
37 \\
8\end{array}$ & $\begin{array}{l}28.6 \\
58.7 \\
12.7\end{array}$ & $\begin{array}{c}5 \\
13 \\
21\end{array}$ & $\begin{array}{l}12.8 \\
33.3 \\
53.8\end{array}$ & $\begin{array}{c}3 \\
22 \\
39\end{array}$ & $\begin{array}{c}4.7 \\
34.4 \\
60.9\end{array}$ & 37.5 & $\mathrm{p}<0.001 * *$ \\
\hline $\begin{array}{l}\text { Current smoking: } \\
\text { Non smokers } \\
\text { Smokers }\end{array}$ & $\begin{array}{l}33 \\
30\end{array}$ & $\begin{array}{l}52.4 \\
47.6\end{array}$ & $\begin{array}{l}16 \\
23\end{array}$ & $\begin{array}{l}41.1 \\
58.9\end{array}$ & $\begin{array}{l}24 \\
40\end{array}$ & $\begin{array}{l}37.5 \\
62.5\end{array}$ & 3.03 & $\mathrm{p}>0.05$ \\
\hline
\end{tabular}

$\chi 2$ : Chi-Square test

**: Highly statistically significant

Table (3) showed that the number of meals was statistically significantly fewer (2 meals/day) among security guards with night shift (68.7\%) than those with evening and day shifts (38.5\% and $23.8 \%$ respectively). The number of snacks ( $>3$ snacks/ day) was statistically significantly higher among those with night shift (54.7\%) than those with evening and day shifts (12.8\% and 6.3\% respectively). The time of last meal was after 12 am in a higher percentage of security guards with night shift (60.9\%) than those with evening and day shifts (53.8\% and $12.7 \%$ respectively). There was a highly statistically significant difference between the three groups as regards the number of meals and snacks/day and the time of last meal $(\mathrm{p}<0.001)$. There was no statistically significant difference between the three groups as regards current smoking $(\mathrm{p}>0.05)$. 
Table (4): Distribution of the daily nutrients intake (macronutrients, minerals and vitamins) among the security guards according to the type of their work shift.

\begin{tabular}{|c|c|c|c|c|}
\hline Nutrient & $\begin{array}{l}\text { Day shift } \\
(\mathrm{No}=63)\end{array}$ & $\begin{array}{l}\text { Evening shift } \\
\qquad(\mathrm{No}=39)\end{array}$ & $\begin{array}{l}\text { Night shift } \\
(\mathrm{No}=64)\end{array}$ & $\begin{array}{c}\text { Test of } \\
\text { significance }\end{array}$ \\
\hline \multicolumn{5}{|l|}{ A. Macronutrients } \\
\hline Total calories (Kcal) & $\begin{array}{c}2083.0(1246.6- \\
3009.8)\end{array}$ & $\begin{array}{c}2231.0(1129.2- \\
4401.4)\end{array}$ & $\begin{array}{c}2356.0(1122.8- \\
4778.2)\end{array}$ & $\begin{array}{c}\mathrm{KW}=5.4 \\
\mathrm{p}>0.05\end{array}$ \\
\hline Carbohydrate (gm) & $278.6(157.8-430.2)^{\mathrm{A}}$ & $\begin{array}{c}289.5(101.1- \\
754.1)^{\mathrm{B}} \\
\end{array}$ & $\begin{array}{c}356.2(167.3- \\
584.6)^{\mathrm{AB}}\end{array}$ & $\begin{array}{r}\mathrm{KW}=12.5 \\
\mathbf{p}<\mathbf{0 . 0 1} *\end{array}$ \\
\hline Protein (gm) & $95.3(28.4-160.7)^{\mathrm{A}}$ & $\begin{array}{c}81.4(32.8- \\
156.2)\end{array}$ & $\begin{array}{c}6.7(19.4- \\
174.8)^{\mathrm{A}} \\
\end{array}$ & $\begin{array}{r}\mathrm{KW}=8.18 \\
\mathbf{p}<\mathbf{0 . 0 5 *}\end{array}$ \\
\hline Fat (gm) & $73.3(28.2-127.1)^{\mathrm{A}}$ & $\begin{array}{c}82.9(22.2- \\
184.6)^{\mathrm{B}} \\
\end{array}$ & $\begin{array}{c}102.3(40.2- \\
135.6)^{\mathrm{AB}} \\
\end{array}$ & $\begin{array}{c}\mathrm{KW}=20.0 \\
\mathbf{p}<\mathbf{0 . 0 0 1} * *\end{array}$ \\
\hline \multicolumn{5}{|l|}{ B. Minerals: } \\
\hline Iron (mg) & $14.7(5.4-27.7)^{\mathrm{A}}$ & $12.7(5.1-30.4)^{\mathrm{B}}$ & $9.6(4.8-18.1)^{\mathrm{AB}}$ & $\begin{array}{l}\mathrm{KW}=15.2 \\
\mathbf{p}<\mathbf{0 . 0 0 1} *\end{array}$ \\
\hline $\mathrm{Ca}(\mathrm{mg})$ & $673.1(182.6-2224.6)^{\mathrm{A}}$ & $\begin{array}{c}635.3(159.7- \\
3393.3)^{\mathrm{B}}\end{array}$ & $\begin{array}{c}488.9(166.7- \\
1403.8)^{\mathrm{AB}}\end{array}$ & $\begin{array}{l}\mathrm{KW}=7.5 \\
\mathbf{p}<0.01 *\end{array}$ \\
\hline $\mathrm{Na}(\mathrm{mg})$ & $2599.0(567.4-6389.5)$ & $\begin{array}{c}3203.0(1304.0- \\
7630.1)\end{array}$ & $\begin{array}{c}3070.0(1260.3- \\
7141.5)\end{array}$ & $\begin{array}{c}\mathrm{KW}=4.3 \\
\mathrm{p}>0.05\end{array}$ \\
\hline $\mathrm{K}(\mathrm{mg})$ & $\begin{array}{c}2051.0(800.4- \\
4646.9) \\
\end{array}$ & $\begin{array}{c}2335.0(648.4- \\
5663.2)\end{array}$ & $\begin{array}{c}2212.0(828.1- \\
5444.5)\end{array}$ & $\begin{array}{c}\mathrm{KW}=5.2 \\
\mathrm{p}>0.05\end{array}$ \\
\hline$\# \mathrm{Ph}(\mathrm{mg})$ & $912.2(257.9-1821.9)$ & $\begin{array}{c}962.2(195.4- \\
1821.9) \\
\end{array}$ & $\begin{array}{c}1085.0(142.2- \\
1821.9) \\
\end{array}$ & $\begin{array}{c}\mathrm{KW}=2.4 \\
\mathrm{p}>0.05\end{array}$ \\
\hline \multicolumn{5}{|l|}{ C. Vitamins } \\
\hline Vitamin A (IU) & $255.5(10.3-1419.2)^{\mathrm{A}}$ & $\begin{array}{c}247.4(41.8- \\
2077.9)^{\mathrm{B}}\end{array}$ & $\begin{array}{c}164.4(47.5- \\
845.6)^{\mathrm{AB}}\end{array}$ & $\begin{array}{c}\mathrm{KW}=8.15 \mathrm{p} \\
<\mathbf{0 . 0 1} *\end{array}$ \\
\hline Vitamin C (mg) & $34.253 .7 \pm$ & $33.164 .8 \pm$ & $32.595 .02 \pm$ & $\begin{array}{c}F=1.5 \\
p>0.05\end{array}$ \\
\hline Thiamine,B1 (mg) & $0.7(0.1-2.6)$ & $0.7(0.1-2.3)$ & $0.5(0.1-1.8)$ & $\begin{array}{l}\mathrm{KW}=4.5 \\
\mathrm{p}>0.05\end{array}$ \\
\hline Riboflavin,B2 (mg) & $0.9(0.1-3.0)^{\mathrm{A}}$ & $0.7(0.2-3.9)$ & $0.5(0.2-3.8)^{\mathrm{A}}$ & $\begin{array}{l}\mathrm{KW}=6.75 \\
\mathbf{p}<\mathbf{0 . 0 5 *}\end{array}$ \\
\hline
\end{tabular}

KW: Kruskal Wallis test

F: One Way ANOVA test

\# Ph: Phosphorus

A/B: Similar letters denote significant difference between groups in same row.

*: Statistically significant **: Highly statistically significant

All parameters described as median (Min-Max) except Vit $\mathrm{C}$ as mean $\pm \mathrm{SD}$ 
Table (4) showed that night shift guards had the highest daily total calories [2356.0 (1122.8-4778.2) kcal], carbohydrate [356.2 (167.3-584.6) gm] and fat [102.3 (40.2135.6) gm] intake followed by those with evening [2231.0 (1129.2-4401.4) kcal, 289.5 (101.1-754.1) gm and 82.9 (22.2-184.6) gm] and day shifts [2083.0 (1246.6$3009.8) \mathrm{kcal}, 278.6$ (157.8-430.2) gm and 73.3 (28.2-127.1) gm]. There was a statistically significant difference between those with night and evening shifts and those with night and day shifts as regards daily carbohydrate and fat intake. Also, night shift guards had the lowest daily protein intake [76.7(19.4-174.8) gm] with a statistically significant difference between night and day shift guards $(\mathrm{p}<0.05)$.

As regards minerals, night shift guards had the lowest daily intake of iron [9.6 (4.8-18.1) $\mathrm{mg}$ ] and calcium [488.9 (166.7-1403.8) $\mathrm{mg}$ ] followed by evening [12.7 (5.1-30.4) $\mathrm{mg}$ and 635.3(159.7-3393.3) $\mathrm{mg}$ ] and day shift guards [14.7 (5.4-27.7) $\mathrm{mg}$ and 673.1 (182.6-2224.6) $\mathrm{mg}$ ]. There was a statistically significant difference between those with night and evening shifts and those with night and day shifts as regards daily iron $(\mathrm{P}<0.001)$ and calcium intake $(\mathrm{P}<0.01)$.

Also night shift guards had the lowest daily intake of vitamin A [164.4 (47.5845.6)IU] , vitamin C [32.59 \pm 5.02$]$, thiamine [0.5 (0.1-1.8)] and riboflavin [0.5 (0.2-3.8)] followed by those with evening [247.4 (41.8-2077.9), 33.16 $\pm 4.8,0.7$ (0.1-2.3) and 0.7 (0.2-3.9)] and then day shifts [255.5 (10.3-1419.2), 34.25 $3.7,0.7$ $(0.1-2.6)$ and $0.9(0.1-3.0)]$. There was a statistically significant difference between those with night and evening shifts and those with night and day shifts as regards daily vitamin A intake ( $\mathrm{p}<0.01)$ while there was a statistically significant difference between those with night and day shifts as regards daily riboflavin intake $(\mathrm{p}<0.01)$. 
Table (5): Types of snacks among the security guards according to the type of their work shift.

\begin{tabular}{|l|l|l|l|l|l|l|l|}
\hline \multirow{2}{*}{ Snacks } & \multicolumn{2}{|c|}{$\begin{array}{c}\text { Day shift } \\
\text { (No=63) }\end{array}$} & \multicolumn{2}{c|}{$\begin{array}{c}\text { Evening } \\
\text { shift } \\
\text { (No=39) }\end{array}$} & \multicolumn{2}{|c|}{$\begin{array}{c}\text { Night shift } \\
\text { (No=64) }\end{array}$} & $\begin{array}{c}\text { Test of significance \& } \\
\text { p value }\end{array}$ \\
\cline { 2 - 7 } & No & $\%$ & No & $\%$ & No & $\%$ & \\
\hline Hot drink & 52 & 82.5 & 32 & 82.1 & 55 & 85.9 & $0.37, p=0.8=\chi 2$ \\
\hline Beverage & 16 & 25.4 & 18 & 46.2 & 44 & 68.8 & $23, \quad$ p $\leq \mathbf{0 . 0 0 1 * *}=\chi 2$ \\
\hline $\begin{array}{l}\text { Chips\& } \\
\text { cakes }\end{array}$ & 13 & 20.6 & 19 & 48.7 & 47 & 73.4 & $35.5, \mathbf{p} \leq \mathbf{0 . 0 0 1 * *}=\chi 2$ \\
\hline $\begin{array}{l}\text { Fruits \& } \\
\text { fruit juice }\end{array}$ & 9 & 14.3 & 6 & 15.4 & 8 & 12.5 & $0.18, p=0.9=\chi 2$ \\
\hline Nuts & 5 & 7.9 & 3 & 7.7 & 4 & 6.3 & $0.15, p=0.9=\chi 2$ \\
\hline
\end{tabular}

$\chi 2$ : Chi-Square test

**: Highly statistically significant

Table (5) showed a higher consumption of hot drinks, beverages, chips and cakes among security guards with night shift $(85.9 \%, 68.8 \%$ and $73.4 \%$ respectively) than those with evening $(82.1 \%, 46.2 \%$ and $48.7 \%)$ and day $(82.5 \%, 25.4 \%$ and $20.6 \%$ ) shifts. There was a high statistically significant difference between the three groups as regards beverages, chips and cakes $(\mathrm{p}<0.001)$. Fruits, fruit juices and nuts showed the least intake among all security guards.

\section{Discussion}

The current study showed that BMI was significantly higher among security guards with night shift than those with evening and day shifts (Table 2). This is in agreement with Antunes et al., (2010) who reported that higher BMI was more prevalent among shift workers independently of age and work duration. Moreover, Ghanbary et al., (2016) conducted a study on military personnel in Southern Iran and revealed that $81.6 \%$ of shift workers had a BMI more than 25 while $86.2 \%$ of day workers had a BMI of less than 25. Also, Zayeri et al., (2015) assessed the relationship between shift work and 
BMI in petrochemical staff and found that the average annual trend of BMI among shift workers was about 0.12 $\mathrm{kg} / \mathrm{m} 2$ higher than day workers which confirms the findings of the present study.

Also, the current study revealed that the waist circumference was significantly higher among those with night shift than those with evening and day shifts (Table 2). This is in agreement with Ghanbary et al., (2016) who revealed that that waist circumference was higher among shift workers than day workers. They found that $80.3 \%$ of shift workers had a waist hip ratio (WHR) higher than 0.9 while day workers had a WHR of less than 0.90. Also, Di Lorenzo et al., (2003) studied the effect of shift work on waist circumference in a study performed in 319 glucose-tolerant men working in a Southern Italian industry and found that shift work has impact on waist circumference. The explanation of increased body weight among shift workers may be due to changes in their dietary habits and also the disruption of the circadian rythm (Heath et al., 2012).

The present study showed that the number of meals was significantly fewer ( 2 meals/day) and the number of snacks was significantly higher (> 3 snacks/ day) among security guards with night shift than those with evening and day shifts (Table 3). This is in accordance with Sahu and Dey (2011) who found that nurses in Bengal who worked in night shifts showed significantly low number of full meals per 24 hour while the numbers of snacks were significantly higher compared to morning and afternoon shifts and off day. Similarly, Wong et al., (2010) in their study among nurses in Hong Kong reported that shift duties were positively associated with abnormal eating behavior among nurses working in hospitals. In the contrary to the present study, Seibt et al., (2015) reported no significant difference in the nutritional behavior among hotel staff in Germany working with alternating and regular shifts.

The present study revealed that the time of last meal was after 12 am in a significantly higher percentage of night shift guards than those with evening and day shifts (Table 3). In contrast, Sahu and Dey (2011) reported that nurses with night shift had dinner too early before leaving the duty $(22.05 \pm 0.41 \mathrm{hrs})$ with a statistical difference compared to other two shifts and off day.

The present study reported that night shift guards had the highest daily total caloric, carbohydrate and fat intake 
followed by those with evening and day shifts. There was a statistically significant difference between those with night and evening shifts and those with night and day shifts as regards daily carbohydrate and fat intake (Table 4). This is in accordance with the study carried out by Morikawa et al., (2008) who found that the total energy and carbohydrate intake were the highest among shift workers $>30$ years with midnight shifts, followed by shift workers without midnight shifts and fixed day workers; there was a significant difference as regards total energy intake between shift workers with midnight shifts and fixed day workers among age groups 30-39 and 50-59 years old workers. However, they found that shift workers with midnight shifts had the lowest fat intake.

In contrast, Sahu and Dey (2011) found that the energy, carbohydrate and fat intake in night shift nurses were significantly lower than the other two shifts and off day. Moreover, Naghashpour et al.,(2013) conducted a study among female nurses from six educational hospitals in Ahvaz, Iran and reported that total caloric intake was lower among shift workers $(1637.1 \pm 542.6 \mathrm{kcal} / \mathrm{d})$ compared to day time workers $(1859.7 \pm 539.8$ $\mathrm{kcal} / \mathrm{d})$.
It is obvious that the previous studies although few but revealed low fat intake among night shift workers unlike the current study which reported highest fat intake among night shift workers. This may be explained that although guards with night shifts took few meals per day, they try to compensate it by taking more snacks which contain higher fat and carbohydrate content. Moreover, guards with night shift work from 8.00 pm-8.00 am so their shift is long enough to take more snacks and fast foods. It has been reported that the total energy and nutrient intakes increase when individuals eat with others (Castro, 1997).

The current study reported a significantly higher consumption of beverages, chips and cakes among security guards with night shift than those with evening and day shifts (Table 5).

Also, night shift guards had the lowest daily protein intake with a statistically significant difference between night and day shift guards (Table 4). This is in agreement with Morikawa et al., (2008) who found that the protein intake was the lowest among shift workers with midnight shift. Similarly, Sahu and Dey (2011) found that protein intake was significantly low among nurses when they work in night shift than the other two shifts and off day. 
Also, the current study revealed that night shift guards had the lowest daily intake of iron and calcium followed by evening and day shift guards. There was a statistically significant difference between those with night and evening shifts and those with night and day shifts as regards daily iron and calcium intake (Table 4). This is in agreement with Morikawa et al., (2008) who found that iron and calcium intake were the lowest among shift workers of all age groups with midnight shift than workers without midnight shifts and fixed day workers. There was a statistically significant difference as regards calcium intake between workers of the age group 20-29 yrs with midnight shift and those without midnight shifts and fixed day workers.

Similarly, Naghashpour et al.,(2013) detected that iron and calcium intake were lower among nurses in Iran with shift work compared to day time nurses with a statistically significant difference as regards iron intake.

The present study reported that night shift guards had the lowest daily intake of vitamin A, vitamin $\mathrm{C}$, thiamine and riboflavin followed by those with evening and day shifts. There was a statistically significant difference between those with night and evening shifts and those with night and day shifts as regards daily vitamin A intake while there was a statistically significant difference between those with night and day shifts as regards daily riboflavin intake (Table 4). This is in accordance with Karlsson et al., (2003) and Morikawa et al., (2008) who found that vitamin $\mathrm{A}$ and thiamine intake were the lowest among shift workers of age groups $<50 y r s$ with midnight shift than workers without midnight shifts and fixed day workers. There was a high statistically significant difference as regards vitamin A intake between workers of the age group 20-29 yrs with midnight shift and those without midnight shifts and fixed day workers. There was a statistically significant difference as regards thiamine intake between workers of the age group 3039 yrs with midnight shift and those without midnight shifts and fixed day workers $(\mathrm{p}<0.05)$.

Similarly, Naghashpour et al.,(2013) reported that retinol, ascorbate, thiamine and riboflavin intake were lower among shift workers compared to day time workers with a statistically significant difference as regards thiamine and riboflavin intake $(\mathrm{p}<0.05)$. 


\section{Study Limitation}

This is a cross-sectional study which does not prove cause effect relationship

(it is an association between shift work and dietary intake) that needs a

longitudinal study.

Also it involved a small number of a single occupational group (security guards) at a single university, thus its results cannot be generalized to both security guards in other sectors and other shift workers in different jobs at the community level.

\section{Conclusion and recommendations}

Shift work is associated with unhealthy dietary habits and nutritional imbalances accompanied by deficiencies of protein, iron, calcium, vitamins A, thiamine and riboflavin intake and increase of both carbohydrate and fat intake among the security guards. The effect of work shift is much more observed among security guards with night shift followed by those with evening and day shifts. This is explained by intake of fewer meals with many snacks during their shift. Health education programs should be directed to security guards whose duties require night shifts in order to improve their faulty dietary habits. It is recommended that in Mansoura University where shift work is mandatory, trained healthcare personnel should frequently assess the nutritional status of the security guards in order to minimize the occupational health hazards and enhance their performance.

\section{Conflict of interest}

Authors have declared that no conflict of interests exists.

\section{Acknowledgement}

The author would like to acknowledge the contribution of all employees who participated in this study.

\section{References}

1. Antunes LC, Levandovski R, Dantas G, Caumo W and Hidalgo MP (2010): Obesity and Shift Work: Chronobiological Aspects. Nutr Res Rev; 23(1):155-68.

- Available at: http://dx.doi.org/10.1017/ S0954422410000016

2. Berger AM and Hobbs BB (2006): Impact of Shift Work on the Health and Safety of Nurses and Patients. Clin J Oncol Nurs; 10(4): 465-71. Available at http://dx.doi. org/10.1188/06.CJON.465-471 
3. Castro JM (1997): Socio-Cultural

Determinants of Meal Size and

Frequency. Br J Nutr; 77: 39-55. http://

dx.doi.org/10.1079/BJN19970103

4. Di Lorenzo L, De Pergola G, Zocchetti C, L'Abbate N, Basso A et al., (2003): Effect of shift work on body mass index: results of a study performed in 319 glucosetolerant men working in a Southern Italian industry. Int J Obes Relat Metab Disord; 27(11):1353-8.

5. Ghanbary SA, Ashnagar M, Habibi E, Nowrouzi I and ghasemi H (2016): The relationship of body mass index and waist-hip ratio with shift work among military personnel in 2016. JOHE; 4(4): 252-9.

6. Ghiasvand M, Heshmat R, Golpira R, Haghpanah V, Soleimani A et al.,(2006):

Shift Working and Risk of Lipid Disorders: A Cross-Sectional Study. Lipids Health Dis; 5 (1): 9. Available at: http://dx.doi.org/10.1186/1476-511X-5-9.

7. Godinho MR, Ferreira AP, Greco RM, Teixeira LR and Teixeira MT (2016): Work ability and health of security guards at a public University: a cross-sectional study.Rev.LatinoAm.deEnfermagem;24:2725.

Available at: http://dx.doi. org/10.1590/1518-8345.0616.2725 day.

8. Heath G, Roach GD, Dorrian J, Ferguson SA, Darwent D et al., (2012): The effect of sleep restriction on snacking behaviour during a week of simulated shiftwork. Accid Anal Prev; 45:62-7.
9. Karlsson BH, Knutsson AK, Lindahl BO and Alfredsson LS (2003): Metabolic disturbances in male workers with rotating three-shift work. Results of the WOLF study. Int Arch Occup Environ Health ; 76(6):424-30.

10. Morikawa Y, Miura K, Sasaki S, Yoshita K, Yone-yama S, et al.,(2008): Evaluation of the Effects of Shift Work on Nutrient Intake: A Cross Sectional Study. J Occup Health; 50(3):270-8.Available at: http:// dx.doi.org/10.1539/joh.L7116

11. Morshead DM (2002): Stress and shiftwork. Occup Health \& Safety; 71(4):36-8

12. Naghashpour M, Amani R, Nematpour S and Haghighizadeh M (2013): Dietary, Anthropometric, Biochemical and Psychiatric Indices in Shift Work Nurses. Int J Food Sci Nutr; 4(12):1239-46. doi: 10.4236/fns..412158.

13. National Nutrition Institute (2006): Food Composition Tables for Egypt. 2nd Edition, A.R.E., Cairo, pp.119.

14. Ohtsuka NS (2001): Nutrient intake among female shift workers in a computer factory in Japan. Int J Food Sci Nutr; 52(4): 367-78.

15. Sahu S and Dey M (2011): Changes in Food Intake Pattern of Nurses Working in Rapidly Rotating Shift. Al Ameen J Med Sci; 4(1):14-22. 
16. Seibt R, Süße T, Spitzer S, Hunger B and Rudolf M (2015): Nutrition and health in hotel staff on different shift patterns. Occup Med (Lond); 65(6): 47784. doi: 10.1093/occmed/kqv068. Epub Jun 9.

17. Waterhous J, Buckley P, Edwards B and Reilly T (2003): Measurements of, and Some Reasons for Difference in Eating Habits between Night and Day Workers. Chronobiol Int ; 20(6):1075-92. Available at: http://dx.doi.org/10.1081/CBI120025536

18. Wong H, Wong MCS, Wong SYS and Lee A (2010): The Association between Shift Duty and Abnormal Eating Behavior among Nurses Working in a Major Hospital: A Cross-Sectional Study. Int J Nurs Stud; 47 (8):1021-7. Available at: http://dx.doi.org/10.1016/j. ijnurstu.2010.01.001
19. World Health Organization (1995): Physical Status: The Use and Interpretation of Anthropometry. Geneva CH. WHO, Tech Rep, No. 854, 1995. http://whqlibdoc.who.int/trs/WHO_ TRS_854.pdf

20. World Health Organization (2006): Global database on Body Mass Index: BMI Classification. World Health Organization, Retrieved 16,2016.

21. World Health Organization (2008): Waist circumference and waist-hip ratio: Report of a WHO expert consultation, Geneva, 8-11 December 2008.

22. Zayeri F, Khadem MAA, Hassan ZH, Najafi KA and Salari M (2015): Assessment of the relationship between shift work and body mass index in petrochemical staff using latent growth curve model. Daneshvar Medicine; 22(117):74-84. 